\title{
Why Bubble Economy Occurs and Crashes?_-Repeated History of Economic Growth and Collapse
}

\author{
Eizo Kinoshita \\ Meijo University, Gifu, Japan
}

\begin{abstract}
This paper shows that there are two different phases in economics. These are the primal and dual problems. In the primal problem phase, capital expenditures of private corporations grow, creating an impetus towards the maximization of profits. In this case, as Adam Smith once wrote, the "invisible hand of God" works to lead the economy to a significant growth. This paper defines the concept of economic growth, bubble economy and destruction of bubble economy. And this paper describes why bubble economy occurs and crashes. In the process, this paper shows that primal economy exists before bubble economy and dual economy exists after destruction of bubble economy.
\end{abstract}

Keywords: economic growth, bubble economy, destruction of bubble economy

\section{Introduction}

Through the analysis of the prolonged recession, Japan has experienced during the last 15 years between 1990 and 2005, and the global downfall in stock prices triggered by the bursting of the housing bubble and the sub-prime loan crisis in the United States from 2008 onward. The author has identified two different phases in the study of economics, which are termed the primal problem economy and the dual problem economy. In the primary problem phase, private corporations with good financial conditions invest in plant and equipment, working towards the goal of maximizing profits, which leads the overall economy to expand. However, once every several decades, a bubble economy pops up in a complicated web of dreams and desires in the private sector and eventually bursts. This is when the economy enters the dual problem phase. Under this phase, the value of assets purchased on credit during the bubble period collapses, and the efficiency of investment drops below the market interest rate for corporations with debt. As a result, corporations stay away from capital expenditure and shift their priorities from profit maximization to debt minimization. In other words, during the dual problem phase in macro-economics, the goal of corporations changes from maximization of profit to minimization of debt, leading the overall economy to shrink. For details, please refer to the author's another thesis entitled A Proposal of Primal and Dual Problems in Macro Economics.

This paper aims to explore the mechanisms of occurrence and collapse of a bubble economy, which seems inevitable when the macro economy shifts from the primal problem phase to the dual problem phase. In doing so, the author would like to present a flowchart (see Figure 1), which shows the process of how a bubble occurs from a prime problem economy, how it collapses, and how the macro economy enters into the dual problem phase. The

Eizo Kinoshita, Ph.D., professor, Faculty of Urban Science, Meijo University. 
flowchart is originally presented in A Proposal of Primal and Dual Problems in Macro Economics by the author.

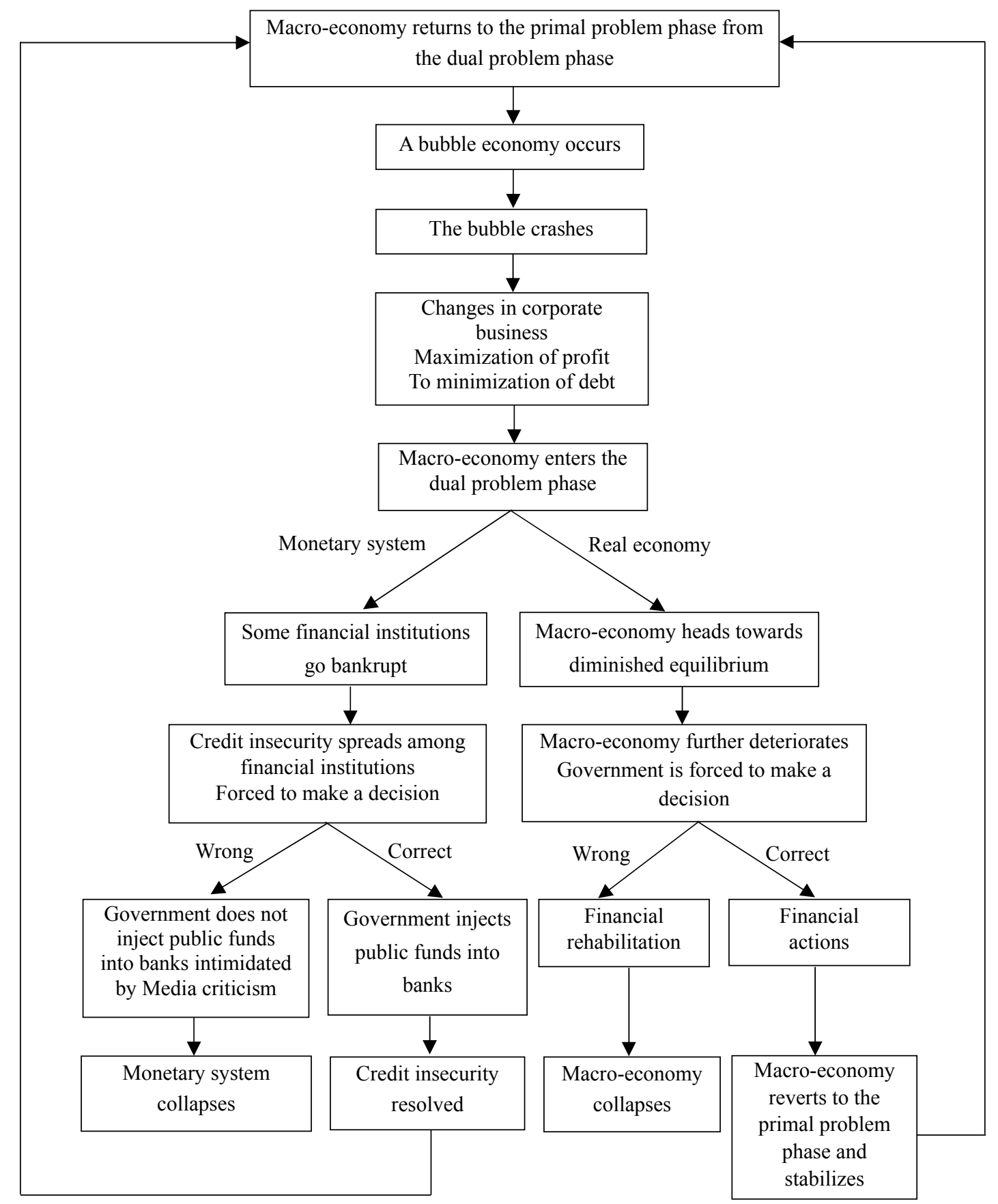

Figure 1. Flowchart of economic cycle.

\section{The Difference Between Economic Growth and a Bubble}

What is the difference between economic growth and a bubble? The question is important because many readers might assume that "a bubble is an excessive form of economic growth". However, economic growth and a bubble are completely different, as is shown in Figure 2.

Figure 2 shows that if corporate investment increases to result in a $(\Delta I)$, the equilibrium point moves from 
$A$ to $A$ ', with the economy heading towards the expanded equilibrium. When corporate investment increases to result in an $I^{l}$, then the economic equilibrium point moves to $A^{l}$. As a result, the economy expands more, which is accompanied by an increase in consumption. When corporate capital expenditure grows more to result in an $I^{2}$, the economic equilibrium point moves to $A^{2}$, bringing the economy to grow further. However, during the process of the transition of the economic equilibrium point from $A \rightarrow A^{\prime} \rightarrow A^{1} \rightarrow A^{2}$, the consumption coefficient $a$ is constant in the demand function:

$$
D=a Y+I
$$

In this instance, $a$ is 0.9 (it can be 0.8 or 0.85 ). The multiplier effect is expressed as follows:

$$
\frac{1}{1-a}=\frac{1}{1-0.9}=10
$$

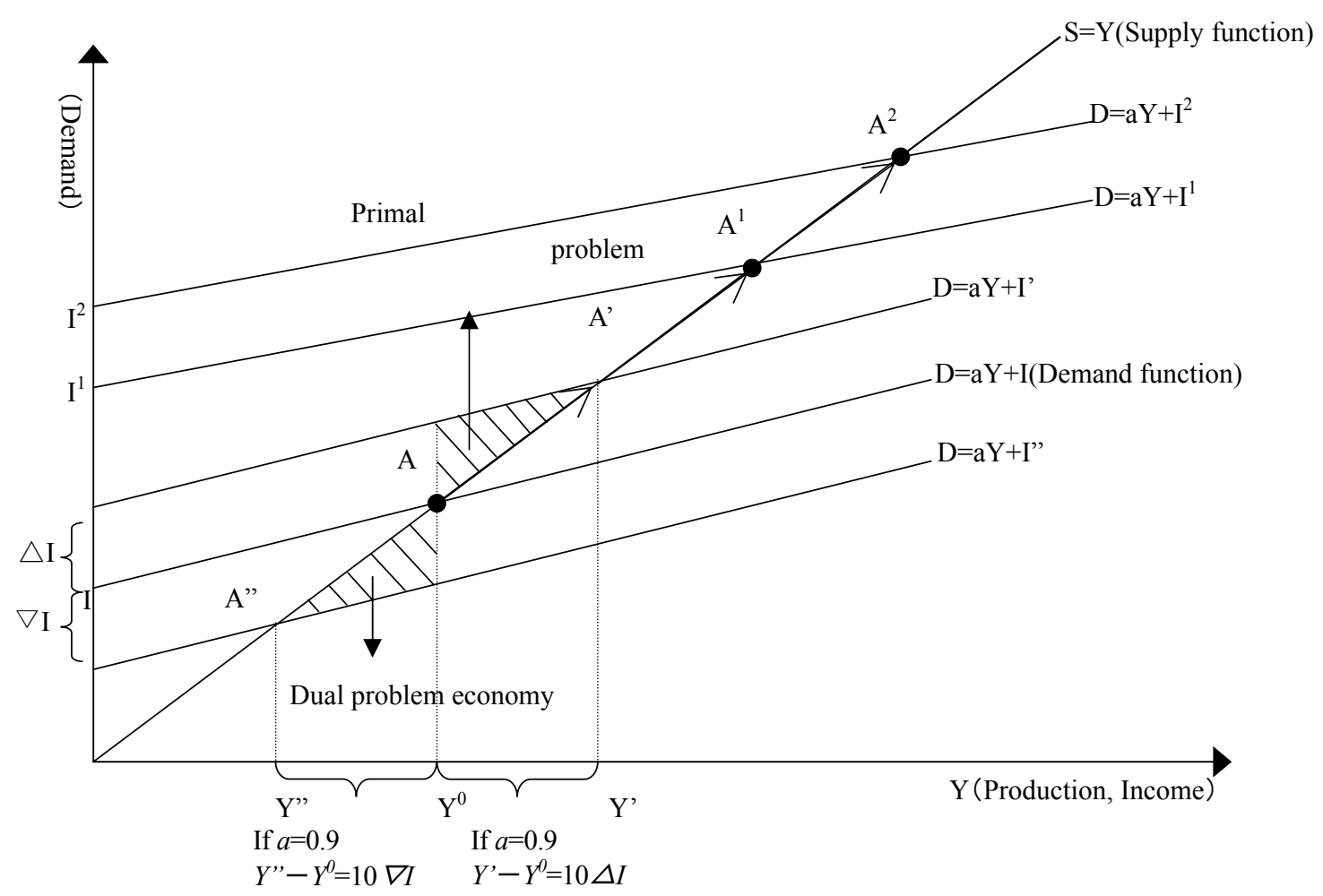

Figure 2. The primal economy and the dual economy. The primal problem economy and the dual problem economy in the chart show a relationship of duality; $I$ : Investment; $Y$ : Gross domestic product; $D$ : Demand; $S$ : Supply; a: Consumption coefficient.

This means that Figure 2 shows economic growth with the multiplier effect of 10 times. The author defines this type of economic expansion as "economic growth", and hopes that readers will recall the definition whenever it is mentioned in the paper.

\section{Cause of the Occurrence of a Bubble}

An increase in private sector demand, during the process of economic growth, may prompt not only private companies to expand capital expenditure, but also individual consumers to engage in speculation. In the United States, for example, even a shoeshine boy purchased stocks for speculation during the 1920s. In Japan, housewives, elderly people, and even students engaged in speculation during the so-called Heisei Bubble of the 
early 1990s. The housing bubble of the United States occurred as an increasingly large number of low-income earners started taking out sub-prime loans after 2005, before U.S. house prices began their steep decline, which triggered the sub-prime mortgage crisis in 2008. It was another example of speculative behavior by the U.S. common folks. In such a state, the consumption coefficient $a$ in the demand function $D=a Y+I$ is infinitely closer to 1 . As a result, its economic effect, or multiplier effect, represented by 1/1-a, grows without limit. Under such circumstances, the economy expands infinitely, even without any increase in corporate capital expenditure. The author defines such a state with abnormally high investment effects as "bubble economy" in this paper. As Figure 3 shows, the economy expands when the consumption coefficient of individual consumers is closer to 1 , even without an increase in corporate investment in facilities. And the economic equilibrium point moves from $A^{\prime}$ to $A^{1}$, and to $A^{2}$. This is the state of a bubble economy.

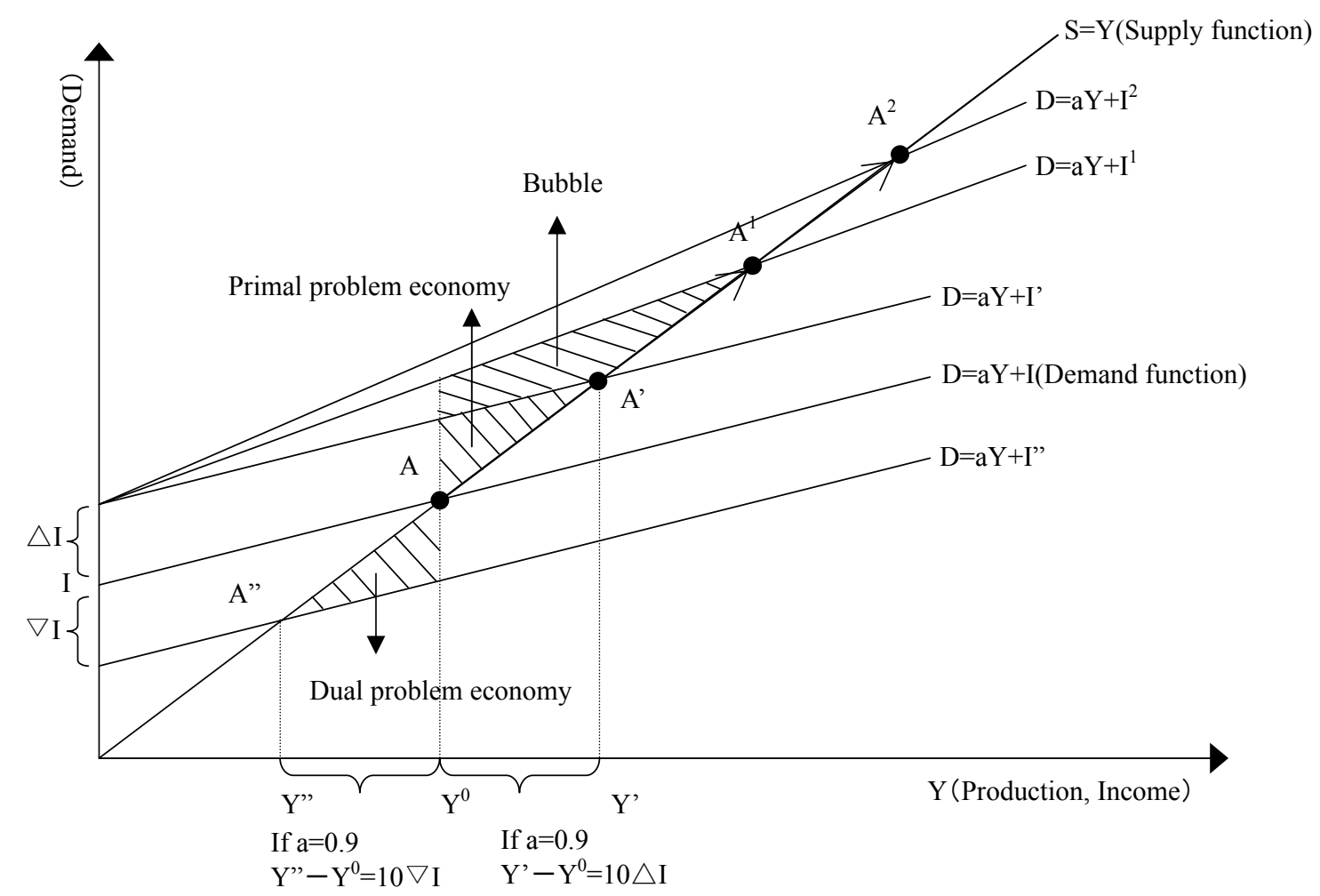

Figure 3. Bubble economy. The primal problem economy and the dual problem economy in the chart show a relationship of duality.

\section{Cause of the Collapse of a Bubble}

A bubble economy is often mistaken to be "an outstanding state of the economy", as is mentioned above. History shows that once an individual gets a forbidden taste of "a bubble economy", his or her enthusiasm for speculation tends to be accelerated. During "the Tulip mania" in the first half of the 17th century in the Netherlands, the fad became so excessive that the price of a single tulip bulb rose as high as the price of a house. However, once the consumption coefficient of this "forbidden state of a bubble" becomes marginally above 1, the bubble collapses. The process is shown in Figure 4.

The mathematical expression of the process is as follows:

$$
Y=C+I
$$




$$
C=a Y
$$

where $Y$ is the gross domestic product, $C$ is total consumer spending, and $I$ is capital expenditure of economic entities (corporations, etc.) in macro-economics.

For instance, if $a=1.1$, then becomes as below:

$$
\begin{aligned}
& Y=C+I \\
& C=1.1 Y
\end{aligned}
$$

The solution for the simultaneous equations is below:

$$
Y=-10 I
$$

It means that when the consumption coefficient grows larger than 1, and corporate capital expenditure increases by a unit $\Delta I$, the economic equilibrium point falls sharply, and the bubble collapses, as is shown in Figure 4. And the economic equilibrium point moves from $A$ to $A$ '. Once people come to recognize this downturn, they tend to refrain from economic activities, which include not only speculation but also consumption. As a result, the overall consumption of the economy shrinks back, and the consumption coefficient marks less than 1 .

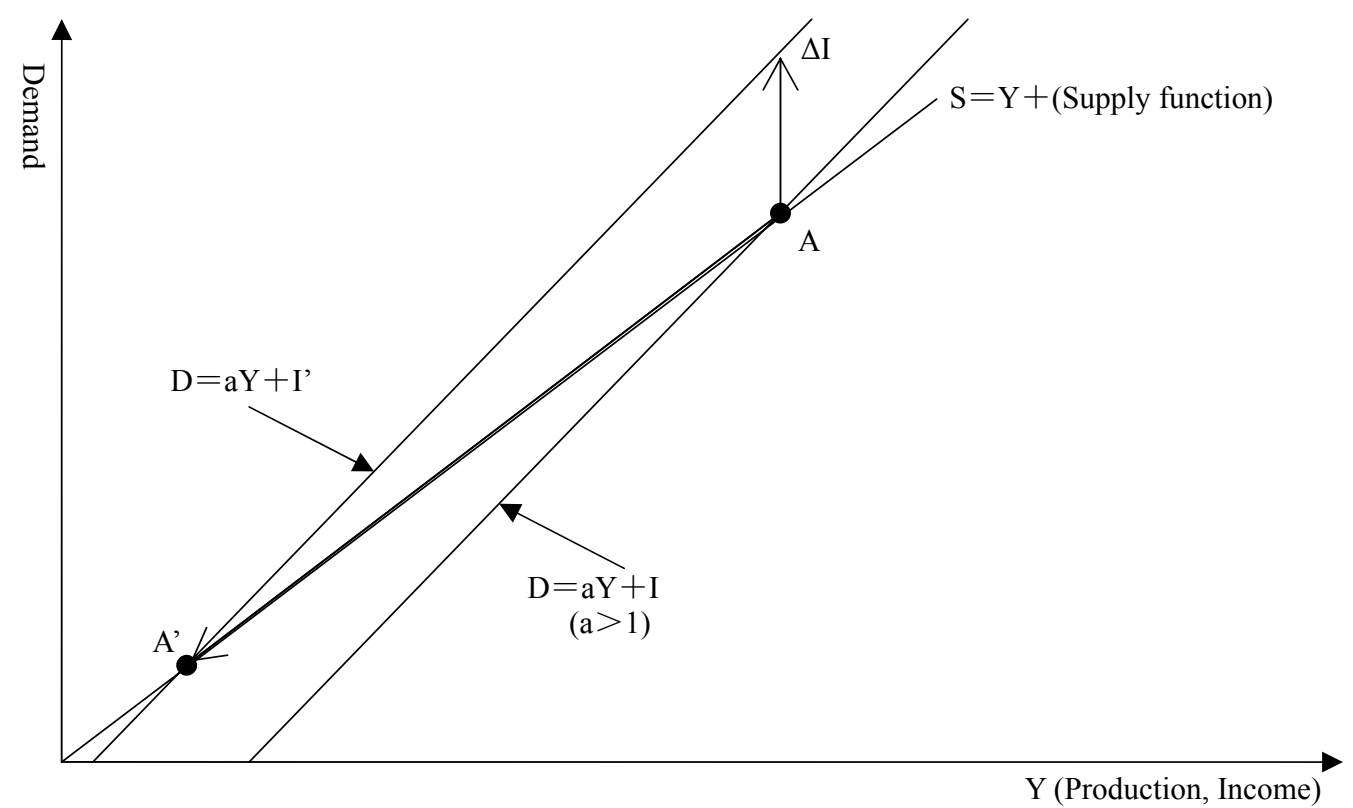

Figure 4. The mechanism in occurrence and collapse of bubble economy.

And consumption activity returns to normal. As a result, however, the economy suffers a great lack of demand as shown in Figure 5. The author defines this state as "collapse of a bubble economy".

As shown in Figure 5, private-sector demand for capital falls sharply. Companies stay away from capital expenditure because investment efficiency goes down to dire levels. In other words, because the value of assets purchased on credit during the bubble period collapses, the efficiency of investment drops below the market interest rate for corporations with debt. As a result, companies discontinue investing in facilities, and shift their business priorities from profit maximization to debt minimization. In this state where the macro economy moves from the primal problem phase to the dual problem phase, with corporate goal shifting from profit maximization to debt minimization, the economy heads for contraction. Just as stated previously, the general public in this economy prefer to save, being reluctant not only to make investments (in stocks and etc.), but also 
to consume for ordinary purposes. Meanwhile, due to low investment efficiency, companies stop borrowing money from banks to make investments; Instead, they become intent on paying down debt. As a result, money is tucked away in the banking system.

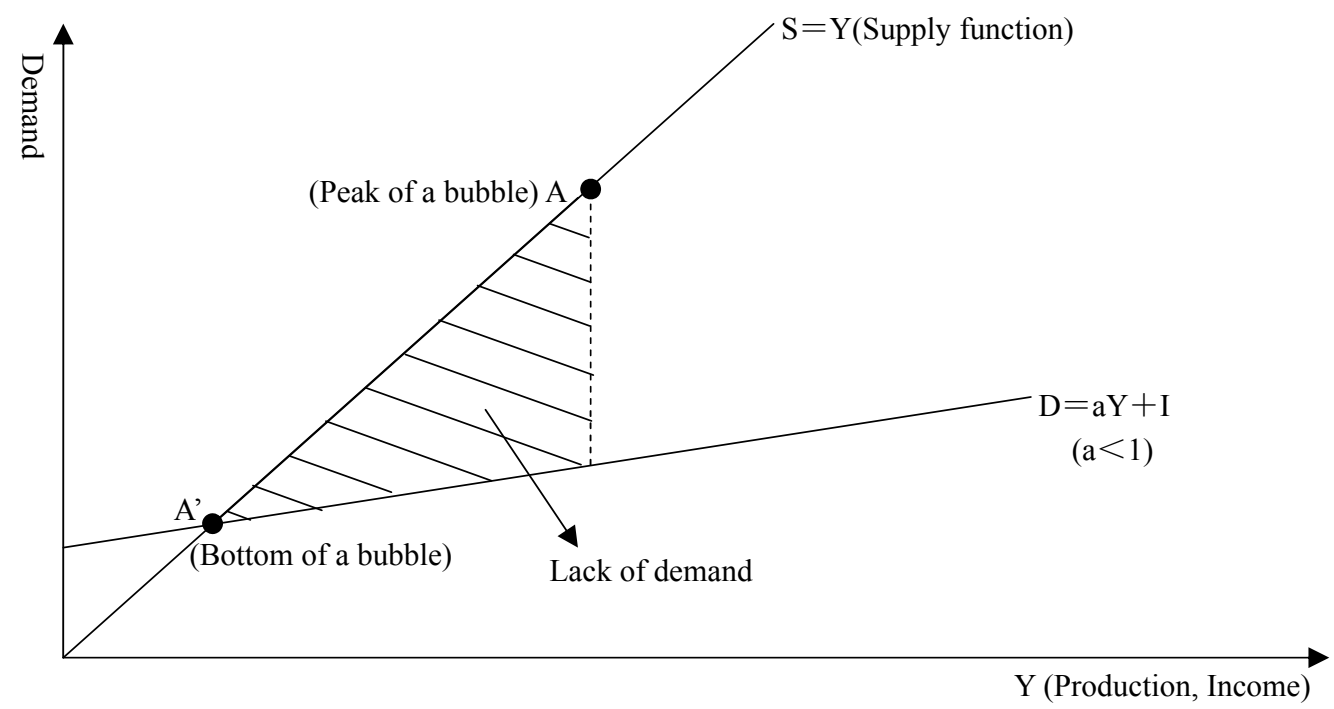

Figure 5. Lack of demand.

\section{Right Policies}

In this phase, the government must adopt fiscal policies to increase public spending and make up for a severe lack of private-sector demand for funds. Spending on public projects is more effective as a measure to increase public spending than tax reduction. In fact, it is the only effective policy to bring the economy from the dual problem phase back to the primal problem phase, as shown in Figure 6, which indicates a flow of money.

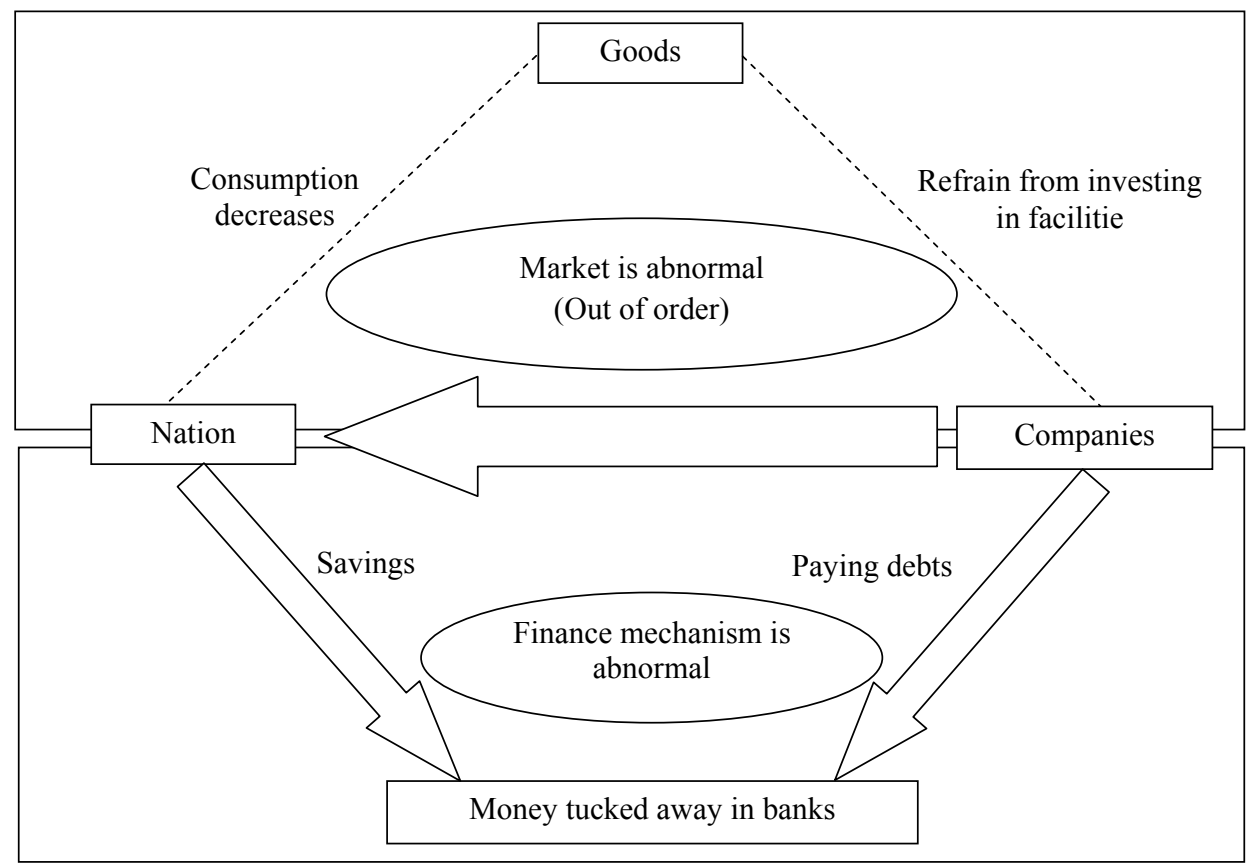

Figure 6. Flow of money in the dual problem phase. The roles of government: (1) Rebuilding the market by public spending; (2) Rebuilding the mechanism of finance by injecting funds into financial institutions. 
As is shown in Figure 6, when the market is out of order, and the mechanism of finance is not functioning properly, the government must adopt fiscal policies to increase public spending. It must also inject public funds into financial institutions for the recovery of the mechanism of finance.

Figure 7 indicates the flow of money after the economy reverts to the primal problem phase.

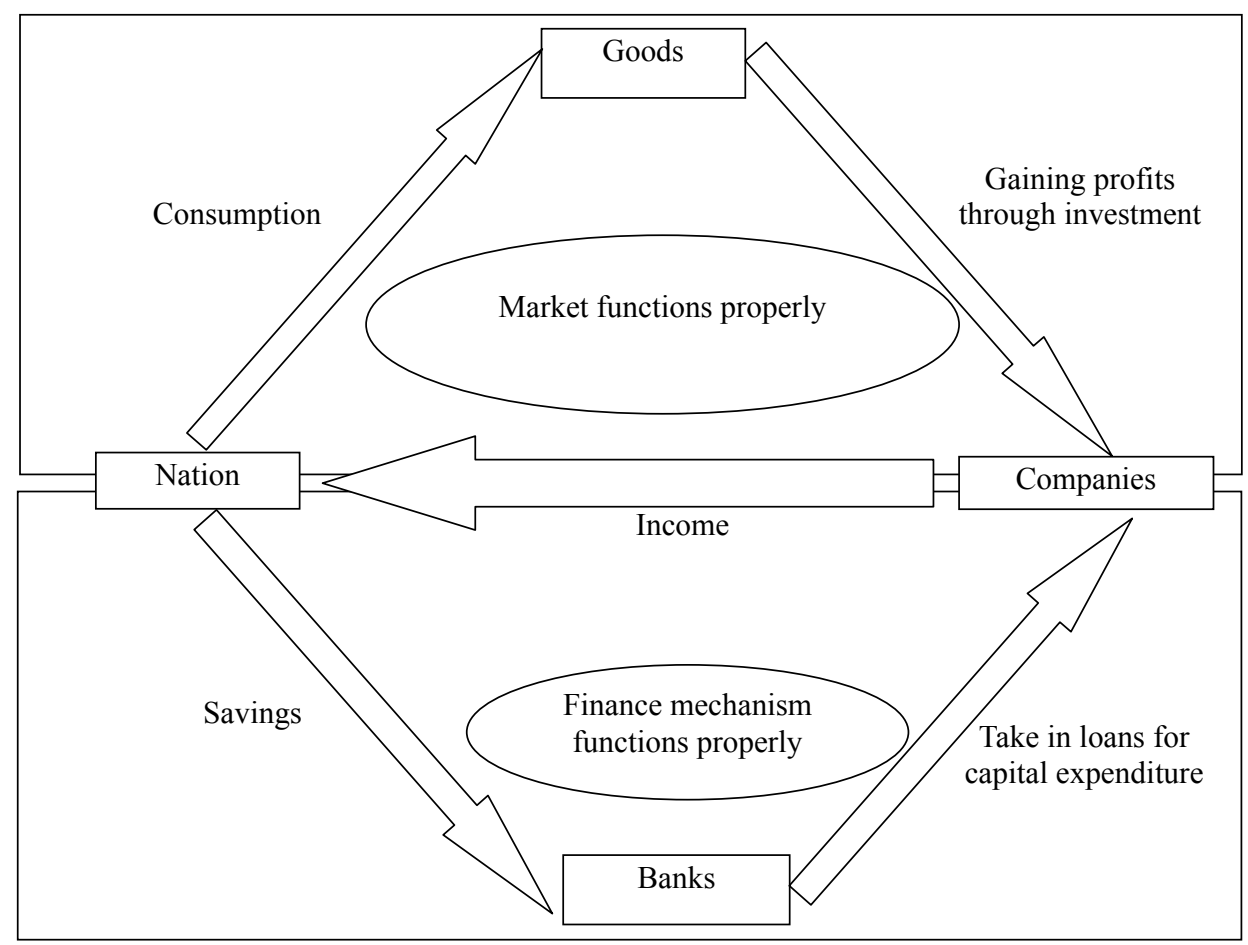

Figure 7. Flow of money in the primal problem phase. The role of the government: leaving to the market.

As shown in Figure 7, the government can remain an observer in this phase, because both the market and the mechanism of finance function properly. If there is work to be done in this phase, the government needs to halt cyclical depression and to prevent the occurrence of a bubble through interest rate operation as part of its monetary policy.

In this context, the so-called "from the public to the private sector" policies, which aimed to promote privatization and de-regulation, adopted by the administration under Junichiro Koizumi were irrelevant. This was because the Japanese economy while he was in power (between 2001 and 2005) was in the dual problem phase. The "from the private to the public sector" type policies, instead of his privatization-oriented policies, were the right choice for Japan in this phase. However, the Koizumi administration privatized postal services and highway public corporations, and established JP Bank and Nippon Road Co, respectively. But the measure only intensified competition in the private sector where the demand for funds remains dull, and weighed on companies. Whereas the policies to break up and privatize Japan National Railways, and to establish JR, adopted and implemented by the government led by Yasuhiro Nakasone were the right choice. This is because the economy was in the primal problem phase during the time of Nakasone Administration. In this phase, it was relevant to adopt "from the public to the private sector" type policies. As history illustrates, the quality of services and management of the railway improved greatly after it was privatized.

After the Second World War, U.S. and Japanese governments respectively adopted economic policies 
which were appropriate for the dual problem phase, when their economies were in the primal problem phase. Those policies, which included the "Remodeling the Japanese Archipelago (Nihon Retto Kaizo)" policies by the administration led by Kakuei Tanaka, ended in failure.

In the United States, President Herbert Hoover failed to recognize that the economy was in the dual problem phase, and thought that it was in a cyclical downturn in the primal problem phase, while he was in power in the early 1930s. He tried and failed to overcome the economic downturn through structural reform and de-regulation. His policies had an adverse effect on the economy, leading it into the "great depression". President Franklin Roosevelt, who replaced Hoover, implemented his "New Deal" policies, a correct choice during the dual problem phase. His policies, along with fiscal stimulus measures implemented through the nation's war with Japan, led the national economy to recover from the depression. After the Second World War, however, the United States continued to dwell on the success of the "New Deal" policies. The memory of the Great Depression during the 1930s was still fresh, although the U.S. economy already recovered from it and reverted to the primal problem phase. The government continued to implement Keynesian policies, which were similar to "New Deal" policies, inappropriate for the primal problem phase. All the economic policies adopted by the U.S. government at that time ended in failure. It was forced to give up on the past policies, with the famous line "Keynes is dead", and shifted to "small government" oriented policies. In short, "New Deal" policies, U.S. version of the "from the private to the public sector" policies, succeeded because the economy was in the dual problem phase at that time. And "from the public to the private sector" type of policies, or "leaving things to the market (free market)" policies, were the most appropriate for the U.S. economy after the war, because it already reverted to the primal problem phase. Other policy options, or fiscal stimulus, were inadequate after the war, because they could lead to crowding out (exclusion of private sector companies), if conducted during this phase.

Whereas, "Remodeling the Japanese Archipelago (Nihon Retto Kaizo)" type policies, originally designed by Kakuei Tanaka, would have been proved effective if they were implemented during the time when Junichiro Koizumi was in power, because the Japanese economy was in the dual problem phase. However, since the economy was in the primal problem phase while Tanaka was in power, his policies ended in failure. The Tanaka administration was unexpectedly short lived because of this policy failure, in addition to his shady financial dealings scandal.

On the other hand, in Vietnam, a socialist revolution gained success on the economic front, the only case among socialist economies. Although some say the virtuous personality of Ho Chi Minh contributed to its economic stability, the author thinks that it was mainly because the country was in the dual problem phase after the Vietnam War. Just as aforementioned, adopting, "from the public to the private sector" policies is correct for the economy during the primal problem phase, and "from the private to the public sector" policies during the dual problem phase.

\section{Bubble Collapse in History}

There have been five major cases of asset price collapse in history. Among them, the stock market crash in New York in 1929, known as Black Thursday, is the most famous still remembered today. The Great Depression triggered by this freefall on Wall Street, eventually spread to all the capitalist economies. In 1933, the U.S. real GNP dropped to $71 \%$ of the figure in 1929 , with one in every four people unemployed. President Roosevelt adopted his "New Deal" policies to stimulate the economy and to cope with unemployment through 
public projects. It was the world's first attempt to put a theory written by John Maynard Keynes into practice. Keynes theorized a government policy to create effective demand (demand accompanying actual expenditure of currency) by public projects. A British economist born in 1883, Keynes presented this ingenious economic theory in his "the General Theory of Employment, Interest and Money". He argued that economic recovery is possible if a government creates effective demand during an economic depression (particularly, at the time of a great depression involving a plunge in asset prices) when it is low. In this state, called "a mixed economy", a government may intervene in the market to stabilize the economy. In this way, through the implementation of "New Deal" policies, and through the creation of effective demand during the Second World War, the U.S. economy recovered. Keynes passed away in 1946, the year following the end of the war.

Looking into other collapse cases, the first one occurred during the first half of the 17th century, in the Netherlands, which followed "Tulip mania". At the peak of this craze around 1635, a single tulip bulb of some varieties cost more than a luxurious house at that time. It was as if the economy was under the "Tulip standard system", where a tulip bulb was the major standard of value. However, a bubble inevitably bursts. And in 1637, tulip bulb prices started to decline.

The second one occurred after the "South Sea Bubble" in the first half of the 18th century in Britain. The South Sea Company was founded through the involvement of a British politician. People speculated in the company's stocks, which eventually led to a bubble. A similar case took place also in Japan where people speculated in NTT stocks, after they were listed on the market following the privatization of the Nippon Telegraph and Telephone Corporation. The price of NTT stocks skyrocketed, but eventually plunged. The same thing happened in the first half of the 18th century, and the inflated South Sea Company stocks also went down.

The third was Black Thursday in 1929 in the United States as aforementioned. It was followed by the fourth, or the Tokyo stock market crash on February 21, 1990, which led Japan to experience "the lost 15 years".

The fifth was the global downfall in stock prices triggered by the bursting of the housing bubble and the sub-prime loan crisis in the United States. Table 1 indicates the characteristics of the five historical cases of collapse in asset prices.

Table 1

Historical Cases of Plunge in Asset Price

\begin{tabular}{|l|l|l|l|l|l|}
\hline & Tulip mania plunge & South Sea bubble & $\begin{array}{l}\text { New York stock } \\
\text { plunge }\end{array}$ & $\begin{array}{l}\text { Tokyo stock } \\
\text { plunge }\end{array}$ & Sub-prime loan crisis \\
\hline Period & $\begin{array}{l}\text { The first half of 17th } \\
\text { century }\end{array}$ & $\begin{array}{l}\text { The first half of 18th } \\
\text { century }\end{array}$ & $1929-$ & $1990-$ & $2008-$ \\
\hline Country & Netherlands & Britain & United States & Japan & United States \\
\hline Type of asset & Tulip bulbs & Stocks & Stocks & Stocks + Land & Stocks + Land+Bonds \\
\hline Rate of decline & $-93 \%$ & $-84 \%$ & $-87 \%$ & $-86 \%$ & $?$ \\
\hline
\end{tabular}

These five cases share certain characteristics, although types of assets speculated differ from one another (tulip bulbs, stocks, land and bonds): Prices rose excessively, and people were turned on by the inflated value of those assets, before they began to go down.

Rate of sharp decline is another characteristic common with the five cases. However, the outcome of the Tokyo stock market crash, and that of the New York stock market plunge differ greatly. From an angle of GDP, U.S. GDP at the time of New York stock market crash, 80 years ago, declined by over $30 \%$, whereas Japanese 
GDP at the time of Tokyo stock market plunge did not go down (it did not grow either). Whereas the U.S. jobless rate rose to a $25 \%$ level 80 years ago, in Japan, it rose merely to 5 to 6 percent.

In conclusion, the outcome of the fourth case, or Tokyo stock market crash, was a triumph, in which Japan proved that a government can avoid economic depression by implementing fiscal policies. The author hopes that Japan's successful experiences of this fourth case will be made use of in handling the current global depression triggered by the bursting of the housing bubble and the sub-prime loan crisis in the United States.

Lastly, the author would like to share with readers the lesson obtained by working on this paper, which is expressed in the famous line-History repeats itself.

\section{References}

Kinoshita, E. (2009, February). Primal problem economy and dual problem economy (pp. 14-21). Nagoya, Central Japan Industries Association.

Kinoshita, E. (2009, May). Why economics studies make mistakes-Two economic principles overlooked by Marx and Keynes. Tokyo: Tokuma Shoten.

Kinoshita, E. (2004). Two laws that dictate economy. Tokyo: Denki Shoin.

Kinoshita, E. (2010, July). Why bubble economy occurs and crashes (pp.37). 24th European Conference on Operational Research, Lisbon. 